\title{
RINTISAN PEMBANGUNAN KAMPUNG TERNAK-PISANG SEBAGAI DESTINASI WISATA NON BAHARI DI DESA PARAKANMANGGU KABUPATEN PANGANDARAN, JAWA BARAT
}

\author{
Sondi Kuswaryan ${ }^{1 *}$, Reginawanti Hindersah ${ }^{2}$ dan Nia Kurniati ${ }^{3}$ \\ ${ }^{1}$ Fakultas Peternakan Universitas Padjadjaran \\ ${ }^{2}$ Fakultas Pertanian Universitas Padjadjaran \\ ${ }^{3}$ Fakultas Hukum Universitas Padjadjaran \\ E-mail: sondi.kuswaryan@unpad.ac.id
}

\begin{abstract}
ABSTRAK. Sektor pariwisata di Kabupaten Pangandaran adalah penyumbang pendapatan asli daerah terbesar, dengan destinasi andalannya adalah wisata bahari. Tujuan wisata body rafting di perdesaan kurang berjalan optimal karena tidak sesuai untuk wisata keluarga. Wisata berbasis perdesaan dapat dibangun dan selaras dengan wisata non bahari tersebut. Tujuan pengabdian pada masyarakat (PPM) ini adalah menampung aspirasi dan membangun komitmen masyarakat untuk membangun rintisan Kampung Ternak-Pisang. Kegiatan PPM di Desa Parakanmanggu Kecapamatan Parigi Kabupaten Pangandaran dilaksanakan secara campuran luring, daring dan virtual. Kegiatan PPM ini berhasil membangun rintisan Kampung Ternak-Pisang dalam bentuk satu unit kandang domba di Kampung Ternak dan Kampung Pisang dalam bentuk kebun pisang seluas $1.200 \mathrm{~m}^{2}$ di Dusun Parakan. Setelah mengikuti PPM ini masyarakat memiliki keyakinan bahwa membangun destinasi agrowisata tidak selalu membutuhkan invenstasi yang besar. Kajian ini menjelaskan bahwa untuk pengembangan Kampung Ternak dan Kampung Pisang diperlukan langkah (a) Pembentukan forum untuk mewadahi aspirasi. (b). Merancang disain lokasi tujuan wisata. (c). Penyelenggarakan pelatihan kepariwisataan bagi masyarakat. (d). Membentuk kelompok kerja pengendalian lingkungan, sosial budaya, SAR and Rescue (e). Melengkapi transportasi, komunikasi, air, listrik, sarana kesehatan, dan keamanan. Pemerintah perlu meningkatkan perannya, khususnya dalam penyediaan kemudahan akses jalan ke lokasi, serta aturan-aturan yang mendorong dan menjamin kesinambungan pengembangan destinasi wisata di lokasi ini.
\end{abstract}

Kata kunci: Agrowisata; Kampung Ternak; Kampung Pisang; Pedesaan

ABSTRACT. The tourism mainly marine tourism in Pangandaran Regency is a major regional revenue. Body rafting tourism destinations in rural areas are not running optimally due to inconvenient for family. Agrotourism is proposed elsewhere as proper rural-based tourism. The purpose of this community service (CS) was to accommodate the community aspirations and build their commitment to support the Livestock-Banana Village pilot. The program in Parakanmanggu Village, Parigi District, Pangandaran Regency was carried out in a blended or a mixture of offline, online and virtual. This program enables to establish a 1,200 $\mathrm{m}^{2}$-banana garden in Parakanmaggu. After participating the program, the community has confidence that building an agro-tourism destination does not always require a large investment. In order to develop Livestock and banana Village, steps are needed; i.e (a) establish a forum to accommodate community aspirations, (b) design a tourist destinations, (c) organize tourism training for the communities, (d) establish a working group on environmental control, socio-culture, Search and Rescue, and (e) build the infrastructure for transportation, communication, water, electricity, health facility and security. Nonetheless, the government needs to increase its role, particularly in providing better road access to visit the site, as well as regulations that encourage and ensure the sustainable development of tourist destinations in study location.

Keywords: Agrotourism; Livestock Village; Banana Village Rural

\section{PENDAHULUAN}

Pariwisata berperan penting dalam pembangunan nasional, yaitu sebagai penghasil devisa, pemerataan, dan peningkatan kesempatan kerja serta pendapatan masyarakat. Di Indonesia aktivitas pariwisata dijamin oleh peraturan Pemerintah No 50 Tahun 2011 mengenai Rencana Induk Pembangunan Kepariwisataan Nasional Tahun 20102025. Tujuan pembangunan pariwisata nasional adalah menggerakkan perekonomian nasional; dan mengembangkan Kelembagaaan Kepariwisataan dan tata kelola pariwisata yang yang profesional, efektif dan efisien.

Kabupaten Pangandaran memiliki tujuan wisata terutama pantai berskala nasional yang telah dikunjungi wisatawan mancanegara. Tujuan wisata utama Pangandaran adalah Pantai Pangandaran, Batu Hiu, Batu Karas, Mandasari dan Karapyak serta Cagar Alam Pananjung, dan wisata sungai Cukang Taneuh (Green Canyon) dan Citumang. Kunjungan wisata sebelum pandemi Covid-19 meningkat dari tahun ke tahun. Pada tahun 2019 Pangandaran dikunjungi 3.227.296, sedangkan pada 2018 dan 2017 masingmasing ada 2536962 dan 2.457.429 turis berkunjung (BPS, 2020). Pariwisata ini berkembang, selain destinasi wisata yang sudah terkenal serta fasilitas yang lengkap, juga didukung oleh akses jalan yang sangat baik.

Pusat pariwisata Pangandaran adalah wisata bahari padahal Kabupaten Pangandaran memiliki potensi wisata non bahari yang mulai dikembangkan 
oleh masyarakat. Wilayah karst di wilayah dataran tinggi Kecamatan Parigi Pangandaran berpotensi untuk tujuan wisata pengunungan. Formasi karst di desa Selasari and Parakanmanggu membentuk dolina, sungai bawah tanah, mata air dan bukit karst yang penting untuk pertanian (Hindersah etal., 2020). Lebih jauh lagi, karst di pegunungan Pangandaran berasosiasi dengan tanah liat "terra rossa" berwarna merah dengan solum tebal yang telah dimanfaatkan untuk budidaya tanaman pertanian (Hindersah et al., 2021).

Komunitas penduduk di Kecamatan Parigi telah memanfaatkan sungai Citumang, Ciwayang dan Santirah untuk tujuan wisata sungai. Santirah dan Jojogan body rafting di aliran sungi tersebut telah menjadi geowisata lokal di antara bentang alam karst Parigi. Pengelolaan layanan wisata sungai oleh masyarakat lokal telah dikoordinasikan oleh desa, melalui badan usaha milik desa (BUMDES) sehingga penyelenggaraan wisata ini berjalan relatif baik.

Geowisata body rafting kurang sesuai untuk wisata keluarga, padahal Pangandaran banyak dikunjungi keluarga. Body rafting tidak aman untuk anakanak, tidak ada penginapan yang layak dan harus dijangkau dari Kota Pangandaran. Selain itu, Parigi hanya memiliki tujuan wisata body rafting sehingga cenderung ada pemborosan waktu dalam wisata. Pariwisata berbasis pertanian dapat menjadi tujuan wisata saat wisatawan melakukan body rafting. Pariwisata dengan banyak tujuan telah diketahui akan memberi lebih banyak manfaat sekaligus mengubah perilaku wisatawan (Lue et al., 1993, Parroo et al., 2012).

Secara alami wilayah karst di Parigi berasosiasi dengan terra rosa (tanah merah) dengan solum tanah dalam yang sejak lama dimanfaatkan untuk peternakan dan budidaya tanaman darat maupun sawah Saat ini di atas lahan terra rosa petani antara lain beternak domba, serta membudidayakan pisang menjadi salah satu sumber pendapatan penduduk.

Sektor pertanian belum dianggap sebagai potensi destinasi agrowisata. Sampai saat ini belum ada tujuan wisata dengan basis perdesaan, pertanian, peternakan, perkebunan atau kehutanan di kawasan Karst yang kuat menunjang pariwisata di Kabupaten Pangandaran. Pengembangan wisata alami dengan suasana perdesaan menjadi penting dalam pengembangan wisata massal (Sutadi dan Marsongko, 2017). Di wilayah karst, agrowisata telah menjadi pilihan penting karena melibatkan masyarakat sebagai pelaku maupun penerima manfaat (Burri et al., 1999; Wang et al., 2019).

Pengembangan agrowisata di Kecamatan Parigi akan menjadi destinasi yang menarik, karena mempunyai ciri khas, yaitu budidaya pertanian yang dikembangkan di kawasan Karst. Sampai sekarang, agrowisat yang ada di Pangandaran hanyalah Kampung Wisata Cisangkal di Desa Bangunjaya, Kecamatan Langkaplancar. Agrowiata ini diinisasi dan dikembangkan oleh masyarakat setempat secara swadaya tanpa investasi swasta/ pemerintah. Pengembangan agrowisata harus tetap memperhatikan tujuan utama wisatawan, yaitu melakukan perjalanan refreshing (leisure and pleasure) ke suatu tempat di luar lingkungan dan kebiasaan sehari-hari untuk mendapatkan sensasi baru dan menghilangkan rasa bosan (Camilleri, 2018).

Pengalaman dan sensasi baru berkaitn erat dengan pengembangan tujuan wisata perdesaan. Tujuan wisata biasanya mempunyai daya tarik dengan berbagai faktor pendukung, seperti aksesibilitas, amenitas, kearifan lokal dan faktor keamanan yang mendorong seseorang melakukan perjalanan. Untuk mendapatkan sensasi baru yang memberikan efek penyegaran, wisatawan dapat memilih daya tarik dan semua faktor pendukungnya yang bersifat alami atau buatan (Judisseno, 2017).

Pembangunan Kampung Ternak dan Kampung Pisang (Cau dalam bahasa Sunda) dapat menjadi alternatif tujuan wisata baru di Pangandaran. Harapannya Kampung Ternak dan Kampung Cau ini dapat mewadahi segmen wisatawan keluarga, yang mampu menyediakan wahana pembelajaran (eduwisata) bagi wisatawan dan keluarganya, khususnya tentang budidaya ternak dan budidaya pisang. Bagi masyarakat Desa Parakanmanggu, agrowisata diharapkan dapat menuai manfaat atau nilai tambah yang optimal baik dari kunjungan tapi juga dari maupun penjualan produk pertanian serta produk turunannya. Tujuan pengabdian kepada masyarakat ini menampung aspirasi dan membangun komitmen masyarakat, penentuan lokasi wisata dan membangun rintisan Kampung Ternak dan Kampung Cau untuk mengawali pengembangan spot wisata pedesaan.

\section{METODE}

Kegiatan pengabdian kepada masyarakat yang dilakukan oleh Tim di Desa Parakanmanggu Kecapamatan Parigi Pangandaran dalam bentuk inisiasi pembangunan Kampung Ternak dan Kamung Cau dilaksanakan secara blended atau campuran luring, daring dan virtual. Kegiatan luring dilakukan dalam rangka penguatan komitmen serta penentuan lokasi kegiatan antara pihak BUMDES sebagai pengelola wisata lokal, pemilik lahan dan pengelola lokasi, Tim UNPAD serta Penyuluh Pertanian Kecamatan Parigi. Kegiatan daring dilaksanakan pada kegiatan pelatihan, konsultasi, pendampingan dan pendidikan masyarakat untuk meningkatkan 
pemahaman masyarakat akan tujuan dibangunnya Kampung Ternak dan Kampung Cau serta untuk peningkatan keterampilan budidaya ternak dan pisang (Gambar 1). Aktivitas virtual dilakukan pada tahapan perencanaan, penyiapan materi, serta publikasi yang akan dilakukan.

\section{Menampung Aspirasi untuk Membangun Komitmen Masyarakat}

Sosialisasi Kampung Ternak dan Kampung Cau dilakukan kepada masyarakat, khususnya pemilik lahan serta Badan Usaha Milik Desa (BUMDES) sebagai pengelola wisata di tingkat desa. Setelah sosialisasi, dengan fasilitasi dari Tim PPM-UNPAD berhasil dibangun komitmen untuk membangun rintisan agrowisata Kampung Ternak dan Kampung Cau secara mandiri/swadaya masyarakat dengan dukungan dari BUMDES dan pendampingan dilakukan oleh Tim Penyuluh Pertanian Kecamatan Parigi dan Tim PPM - UNPAD.

Dalam proses ini, mendengarkan dan menampung aspirasi masyarakat merupakan bagian penting untuk merealisasikan program yang dicanangkan. Pada prinsipnya disain program harus sepenuhnya mereka pahami serta masyarakat menjadi pelaku dan bagian penting dari program termasuk sebagai penerima manfaat program. Masyarakat harus paham benar bahwa program yang dilaksanakan pada dasarnya adalah aspirasi mereka, dimana keberhasilannya sangat tergantung pada upaya yang mereka sendiri lakukan.

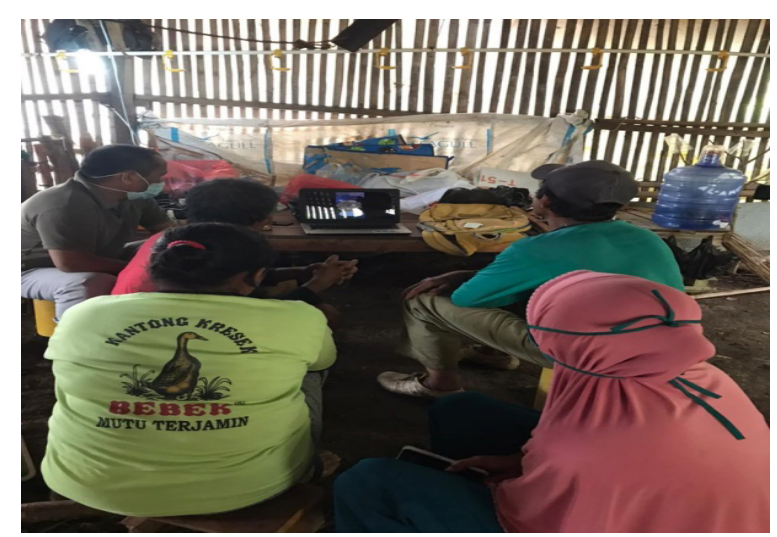

Gambar 1. Penyuluhan Daring

\section{Penentuan Lokasi Tempat Wisata}

Penentuan lokasi pembangunan Kampung Ternak dan Kampung Cau mempertimbangkan kemudahan akses jangkauan wisatawan ke lokasi (jalan), faktor keleluasaan lahan di lokasi (parkir dll), serta kedekatan antar lokasi, sehingga dapat dijangkau dalam satu perjalanan dengan destinasi lainnya.

\section{Pembangunan Kampung Ternak}

Pada prinsipnya pembangunan Kampung Ternak dan Kampung Cau dilakukan dengan cara mengintegrasikan budidaya peternakan sapi dan domba yang sudah ada di lokasi. Sebelum kegiatan, kandang ditata tanpa design, Kegiatan PPM ini adalah perintisan peningkatan kesadaran bahwa kampung ternak bisa didirikan tanpa banyak investasi.

Kampung Ternak adalah suatu lokasi dimana masyarakat lokal melakukan budidaya (breeding, feeding dan management) ternak sapi dan atau domba di satu lokasi, seperti halnya perkampungan (komplek perkandangan) dengan memperhatikan dan menerapkan kaidah-kaidah kepariwisataan. Di Kampung Ternak, pengunjung/wisatawan dapat belajar dan berinteraksi wisata dengan peternak dan ternaknya dengan leluasa.

\section{Pembangunan Kampung Cau (Pisang)}

Kampung Cau adalah suatu lokasi dimana koleksi pisang ditanam, di lokasi tersebut wisatawan dapat menikmati pisang beserta produk turunannya serta dapat belajar tentang budidaya dan manfaat pisang. Kampung Cau dibangun dengan memanfaatkan ketersediaan varitas pisang lokal yang unggul di lokasi, antara lain pisang Lampeneng dan pisang Raja Bulu. Dalam jangka panjang diharapkan dapat dikoleksi berbagai varitas pisang dari seluruh Indonesia, untuk memberikan pembelajaran akan kekayaan ragam pangan di tanah air. Ciri spesifik ini menjadi penting untuk daerah wisata efektif berfungsi, berkembang, dan berkesinambungan (Muftiadi, 2017).

\section{HASIL DAN PEMBAHASAN}

\section{Manfaat Budiaya Ternak, Pisang dan Pengem- bangan Sektor Pariwisata}

Di Desa Parakanmanggu sampai saat ini belum diterapkan paket teknologi tepat guna yang memadukan paket teknologi untuk meningkatkan produktivitas lahan dengan pemeliharaan ternak, budidaya pisang dan sekaligus dengan pengembangan sektor pariwisata secara terintegrasi. Langkah pengintegrasian dinilai cukup rasional, karena petani akan mendapatkan berbagai manfaat lebih banyak, antara lain :

a. Petani dan Peternak memperoleh nilai tambah dan sumber pendapatan dari pisang dan ternak serta penghematan input, karena ada pupuk dari limbah kandang

b. Pohon pisang dapat dibuat cadangan pakan ternak yang berkualitas, untuk penyediaan pakan di musim kemarau.

c. Aktivitas budidaya ternak dan pisang dapat menjadi atraksi menarik bagi wisatawan.

d. Terciptanya lapangan kerja baru dari pariwisata akan meningkatkan pendapatan penduduk lokal (Dhalyana dan Adiwibowo, 2013). 
Pembangunan kepariwisataan disamping menghasilkan nilai tambah juga berdampak pada kerusakan lingkungan, dengan cemaran dari aktivitas wisata. Rintisan kampung ternak dan Kampung Cau yang dibangun di perdesaan sebagai destinasi wisata lingkungan menjadi penting terus didorong dan dikembangkan. Ekowisata berbasis masyarakat merupakan salah satu upaya untuk pengembangan pedesaan tidak hanya semata sebagai destinasi wisata, tapi juga dapat berkontribusi bagi konservasi lingkungan (Tanaya dan Rudianto, 2014).

\section{Lokasi Rintisan Kampung Ternak dan Kampung Cau}

Penentuan lokasi Kampung Ternak dan Kampung Cau (Pisang) di Dusun Parakan Desa Parakanmanggu Kec. Parigi Pangandaran, mempertimbangkan aspek ketersediaan lahan yang memenuhi kelayakan untuk budidaya ternak dan pisang dan cukup luas, akses jalan masuk lokasi, kedekatan dengan lokasi wisata lain serta aspek sosial budaya masyarakat di sekitar lokasi. Hal ini penting untuk diperhatikan karena kedekatan antar lokasi wisata merupakan pilihan menarik bagi para wisatawan untuk menikmati beberapa lokasi wisata dengan mudah (Muftiadi, 2017).

Dalam penentuan lokasi ini, kegiatan sosialisasi menjadi sangat penting karena tidak hanya menyangkut aspek pemilik lahan, tapi juga akan terkait dengan pemilik lahan lainnya. Aspek ekternalitas (positif dan negatif) dari lokasi harus benar-benar dipertimbangkan, supaya di kemudian hari tidak terjadi konflik sosial yang akan merusak program. Berdasarkan kesediaan pemilik lahan dan hasil komunikasi dengan pemilik lahan lainnya, maka disepakati lokasi Kampung Ternak dan Kampung Cau sebagai berikut:

\section{Lokasi Kampung Ternak}

Lokasi yang direncanakan menjadi Kampung Ternak seluas kurang lebih 2 hektar (Gambar 2), pernah digunakan untuk sirkuit motocross, namun saat ini tidak termanfaatkan dan kurang produktif. Keluarga pemilik lahan berkeinginan lahan tersebut dapat produktif dan memberikan manfaat, tidak hanya bagi pemilik lahan, tapi juga untuk masyarakat banyak. Lokasi ini sangat sesuai untuk lokasi perumahan (komplek kandang) ternak, karena akses jalan terbuka, lahan relatif luas dan datar, terdapat sumber air dan sangat mungkin dibangun kebun rumput untuk mendukung budidaya ternak dalam jumlah relatif banyak. Saat ini ada beberapa kandang yang dibangun di lokasi ini, serta sering menjadi tempat penggembalaan ternak atau tempat nyabit rumput oleh penduduk sekitar.

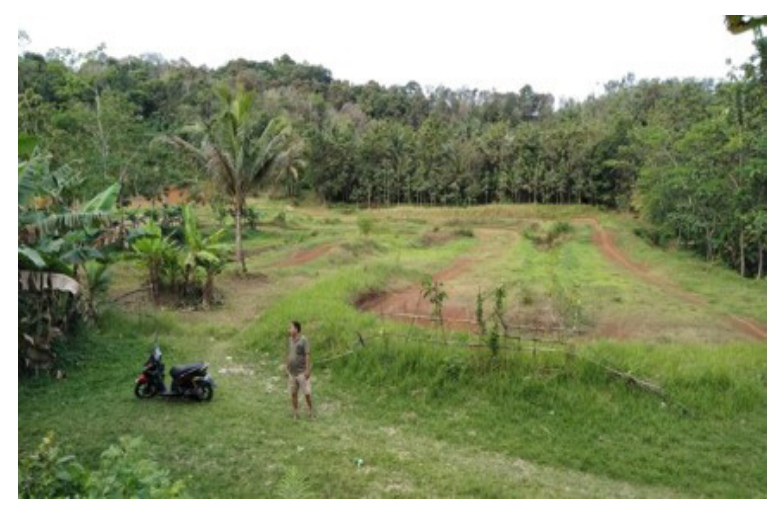

Gambar 2. Kondisi awal lokasi Kampung Ternak

\section{Lokasi Kampung Cau}

Luas lahan yang tersedia sekitar $1.200 \mathrm{~m}^{2}$, merupakan lahan dolina karst, dengan top soil yang cukup tebal, sesuai untuk budidaya pertanian (Gambar 3). Saat ini lahan hanya digunakan untuk pertanian tanaman musiman, namun kurang termanfaatkan secara produktif.

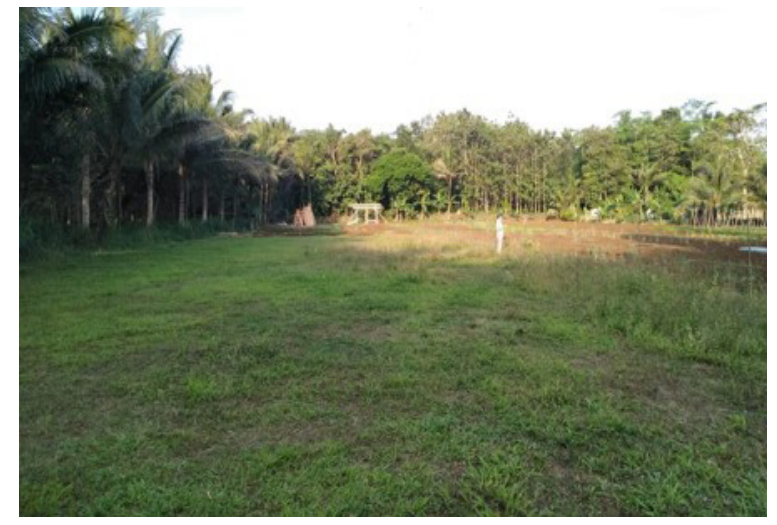

Gambar 3. Kondisi awal lokasi Kampung Cau

Untuk budidaya pertanian, akan lebih baik bila lahan yang ada dilakukan penataan, khususnya dalam penanganan air. Pada musim hujan, banyak air yang tergenang, pada kondisi genangan cukup lama, sering menyebabkan kematian tanaman karena akar membusuk. Pada musim kemarau panjang sering kekurangan air, tanah menjadi retak dan keras. Namun di lokasi ini, masih dapat dibuat sumur air permukaan sebagai sumber air untuk pertanian.

\section{Implementasi Rintisan Kampung Ternak dan Kampung Cau}

Kegiatan ini dilakukan pada 2020 meskipun sebelumnya pada bulan Juli-September 2019 telah dilakukan diskusi intensif dengan para tokoh masyarakat yang ingin memiliki destinasi wisata. Personal yang terlihat pada kegiatan rintisan ini berjumlah 25 orang termasuk Inisiator body rafting Santirah (Abah Kunai), Ketua Gapoktan Parakanmanggu (Bapak Sodikin), staf kantor penyuluh pertanian Parigi (Bapak Iman dan Ibu Iin), serta para pelaku wisata body rafting dan petani. 


\section{Kampung Ternak}

Sebagai rintisan kampung ternak, telah dibangun satu unit kandang domba di lokasi bekas sirkuit motocross di Dusun Parakan (Gambar 4). Untuk memenuhi kelayakan sebagai destinasi wisata diperlukan dukungan dari peternak lainnya, sehingga jumlah kandang menjadi lebih banyak. Partisipasi masyarakat untuk memelihara ternak di kampung ternak sangat diperlukan, tanpa dukungan masyarakat, sangat sulit destinasi wisata kampung ternak diwujudkan. Untuk merealisasikan hal tersebut, diperlukan berbagai kesepakatan yang harus melibatkan berbagai pihak. Hal ini harus mendapat perhatian, karena dalam pengembangan pariwisata berbasis masyarakat, koordinasi dengan masyarakat merupakan bagian penting dalam pembangunan pariwisata (Fauzi dkk,. 2019).

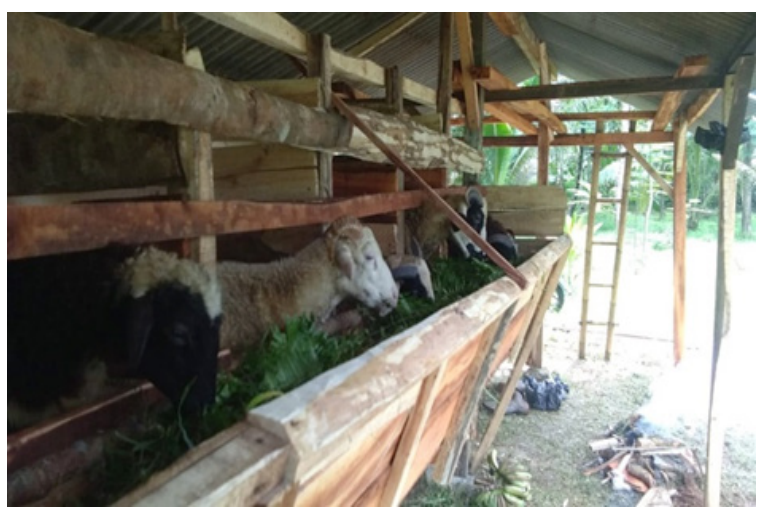

Gambar 4. Kondisi Kandang di Kampung Ternak

Secara teknis di lokasi kampung ternak, disamping sebagai lokasi wisata, juga dapat diintegrasikan menjadi pusat pelatihan peternakan. Sampai saat ini, kebutuhan pakan untuk ternak masih dapat tercukupi dari rumput lapang, tanpa dukungan rumput budidaya. Sebagai lokasi wisata yang layak, dibutuhkan berbagai jenis ternak yang hidup di lokasi tersebut dalam jumlah yang banyak. Oleh karena itu, ke depan diperlukan dukungan kebun rumput dan perangkat teknologi untuk pengolahan dan penyimpanannya, sehingga mampu mendukung kebutuhan hijauan pakan sepanjang tahun.

\section{Kampung Cau}

Sebagai rintisan awal Kampung Cau di Desa Parakanmanggu sudah dapat diwujudkan dengan membuat kebun pisang seluas $1.200 \mathrm{~m}^{2}$ (Gambar 5). Jenis pisang yang sudah ditaman sebagian besar adalah pisang Lampeneng, pisang Raja Bulu, pisang Nangka dan pisang Ambon. Varitas pisang tersebut termasuk jenis pisang yang mempunyai nilai jual tinggi di pasar.

Komunikasi intensif dengan Pak Saiful Iman dari kantor Penyuluh Pertanian dan ketua Bumdes Parakanmanggu Pak Sodikin memberikan pemahaman bahwa masyarakat menaruh perhatian besar terhadap kebun pisang di lokasi Kampung Cau.
Masyarakat belum mengenal teknik budidaya pisang. Mereka hanya menanam tanpa aturan dan pemeliharaan yang benar, sehingga tanaman pisang terkesan seadanya. Dengan penanaman yang teratur pohon pisang lebih asri, nyaman untuk dilihat dan berproduksi dengan optimal sesuai potensi genetiknya (Suhartanto et al., 2012).

\section{Rencana Pengembangan Kampung Ternak dan Kampung Cau}

Untuk mencapai destinasi wisata yang ideal seperti yang disarankan oleh Judisseno (2017) masih dibutuhkan berbagai perangkat dan dukungan berbagai pihak mulai masyarakat, pemeritah daerah (pembinaan dan aturan), NGO, Perguruan Tinggi sampai ke personal volunteer wisata untuk berpartisipasi mendukung terwujudnya Kampung Ternak dan Kampung Cau sebagai destinasi wisata non bahari yang unggul

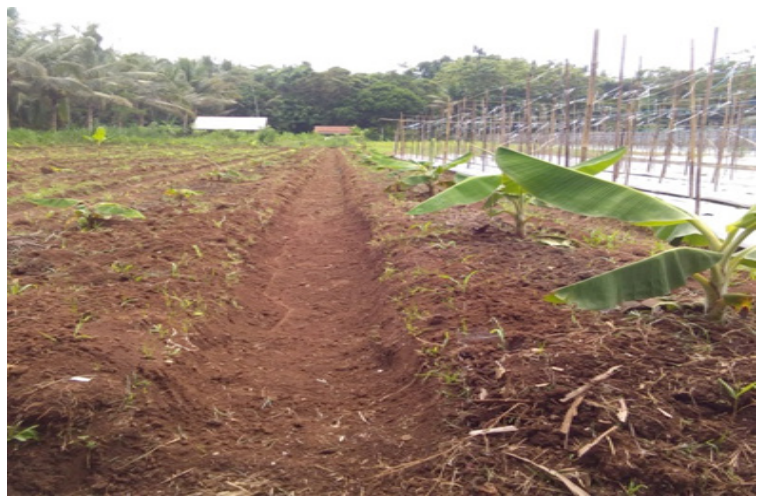

Gambar 5. Tanaman Pisang di Lokasi Kampung Cau

Dalam kontek penerapan Model Community Based Tourism, sebagai stategi pengembangan wisata, menurut harus mempertimbangkan (1). Mengikutsertakan anggota masyarakat dalam pengambilan keputusan, (2). Adanya manfaat langsung oleh masyarakat lokal, dan (3). Pendidikan kepariwisataan pada masyarakat lokal (Ridlwan, dkk, 2017). Langkah yang direkomendasikan oleh Tim peneliti untuk Pengembangan Kampung Ternak dan Kampung Cau adalah :

a. Membentuk forum untuk mewadahi aspirasi masyarakat dalam pengambilan keputusan pengembangan wisata di tingkat desa, terdiri dari pemerintah, BUMDES, pemilik lahan, pengelola lokasi wisata dan pihak lain yang terlibat.

b. Merancang model pembiayaan mandiri pengembangan Kampung Ternak dan Kampung Cau, serta fasilitas pendukung lainnya, dengan melibatkan BUMDES dan investasi masyarakat, supaya nilai tambah dapat optimal diraih oleh masyarakat.

c. Merancang model bagi hasil dari manfaat / nilai tambah yang dihasilkan dari pengembangan wisata, bagi pihak-pihak yang terlibat dalam pengembangan dan pengelola wisata. 
d. Menyelenggarakan pelatihan-pelatihan bagi masyarakat tentang kepariwisataan, antara lain aspek hospitality, story telling (Bakti, dkk, 2018), home stay, produk pendukung pariwisata, wisata yang berkelanjutan dan lain-lain.

e. Membuat dokumen arahan untuk pengen-dalian lingkungan dan budaya, untuk menjaga penurunan kualitas lingkungan dan erosi budaya (Sutadi dan Marsongko, 2017).

f. Merancang disain lokasi Kampung Ternak dan Kampung Cau yang ramah lingkungan dan mempunyai nilai estetika budaya lokal tinggi.

g. Pembentukan kelembagaan tingkat desa yang menangani aspek kesehatan dan pengendalian risiko pariwisata, SAR Rescue.

h. Pembentukan kelembagaan desa yang menangani pengembangan aspek sosial-budaya.

i. Perancangan untuk kelengkapan akses jalan (transportasi), komunikasi, air, listrik, sarana kesehatan, dan keamanan.

Di akhir kegiatan PKM, tim peneliti bersama masyarakat telah membuat kebun pisang seluas 1.250 $\mathrm{m}^{2}$ yang ramah lingkungan. Laporan dari penyuluh petani Parigi, kebun tetap dipelihara intensif termasuk diberi pupuk kandang domba. Masyarakat berharap kebun ini kelak akan menjadi Kampung Cau yang lokasinya bersebelahan dengan kebun sayuran; dan selanjutnya menjadi kawasan agrowisata bersama Kampung Ternak. Pandemi Covid-19 menyebabkan evaluasi lapangan tidak dapat dilakukan.

Secara umum, kegiatan PKM ini telah memberikan pengetahuan baru terkait agrowisata pendukung geowisata bagi sedikitnya 25 masyarakat yang terlibat. Mereka mulai memahami bahwa memperbaiki aspek budidaya ternak dan pisang dapat mendukung agrowisata. Respons yang sangat baik diperlihatkan oleh 6 orang petani dan satu orang tokoh masyarakat yang bersedia membudidayakan pisang dengan sistem yang terstandard. Selama ini pisang hanya ditanam tnapa pemeliharan, ditanam di mana saja tanpa fungi estetik (catatan RH:reviewer meminta Perlu ditambahkan tingkat keberhasilan pelaksanaan kegiatan dan hasil evaluasi)

\section{SIMPULAN}

Masyarakat secara mandiri mempunyai kemampuan untuk memulai mengambil inisiatif melakukan pembangunan destinasi wisata, dalam bentuk rintisan Kampung Ternak dan Kampung Cau. Upaya masyarakat ini harus mendapat dukungan dari berbagai pihak, khususnya pemerintah dalam bentuk sarana, prasarana, dan perangkat aturan yang memungkinkan lokasi ini terus berkembang dan berkesinambungan.

\section{UCAPAN TERIMAKASIH}

Tim Pelaksana PPM menyampaikan ucapan terimakasih kepada Direktorat Penelitian dan Pengabdian kepada Masyakarat Universitas Padjadjaran, yang telah memberikan dukungan untuk berjalannya kegiatan pengabdian dengan baaik. Ucapan terima kasih yang sama disampaikan kepada Tim Penyuluh Pertanian dan Penggiat Pariwisata Non Bahari di Kecamatan Parigi.

\section{DAFTAR PUSTAKA}

Bakti, I. S. Sumartias., T. Damayanti., dan A. R. Nugraha. 2018. Pelatihan Story Telling dalam Membangun Ekonomi Kreatif Bidang Pariwisata di Desa Cintaratu Kecamatan Parigi Kabupaten Pangandaran. Jurnal Bakti Masyarakat Indonesia. Vo. 1. No. 1. Mei 2018. 25-31.

BPS. 2020. Kabupaten Pangandaran dalam Angka 2020. Badan Pusat Statistik Kabupaten Ciamis

Burri, E., B. Castiglioni, U. SauroInt. 1999. Agriculture, Landscape and Human Impact In Some Karst Areas Of Italy. J. Speleol., 28 B (1/4): $33-54$.

Camilleri, M. A. 2018. The Tourism Industry: An Overview. In Travel Marketing, Tourism Economics and the Airline Product (Chapter 1, pp. 3-27). Cham, Switzerland: Springer Nature.

Dhalyana, D dan S. Adiwibowo. 2013. Pengaruh Taman Wisata Alam Pangandaran Terhadap Kondisi Sosial Ekonomi Masyarakat. Sodality: Jurnal Sosiologi Pedesaan. Vol. 01. No. 03. Desember 2013. 181-199.

Fauzi, P., S. Bakhri dan A.A. Ahmad. 2019. Pembangunan Pariwisata di Kabupaten Pangandaran Pasca Pemekaran. Al-Amwal: Jurnal Ekonomi dan Perbankan Syari'ah (2019). Vol 11 (1). 77-94.

Hindersah, R., H. Kurniati, D.E. Sukarsa, Rustam dan S. Kuswaryan. 2020. Sustainable Food Crop Production in Karst Area of Parigi, Pangandaran, West Java: Preliminary Study. Jurnal Perspektif Pembiayaan dan Pembangunan Daerah 8(1):41-50

Hindersah, R. Y. Firmansyah dan N. Kurniati. 2021. Soil properties of agricultural area in karst terrain of Parakan. Pangandaran, West Java, Indonesia Journal of Degraded and Mining Land Management. 8(3): 2809-2814 
Judisseno, R.K. 2017. Aktivitas dan Kompleksitas Kepariwisataan : Mengkaji Kebijakan Pembanguan Kepariwisataan. Penerbit Gramedia Pustaka Utama.

Muftiadi, A. 2017. Pengembangan Desa Wisata dan Potensinya Di Kabupaten Pangandaran. Jurnal AdBispreneur. Vol.2 No. 2, Agustus 2017. 117-124.

Lue, C-C, J. L. Crompton, D. R. Fesenmaier. 1993. Conceptualization of multidestination pleasure trips. Annals of Tourism Research, Vol. 20, 289-301

Suhartanto, R., Sobir dan H. Harti. 2012. Teknologi Sehat Budidaya Pisang. Pusat Kajian Hortikultura Tropika, LPPM-IPB. Bogor

Sutadi, T dan E.P. Marsongko. 2017. Studi Kebijakan Pengembangan Kawasan Pangandaran Sebagai Kawasan Strategis Pariwisata Nasional. Jurnal Kepariwisataan : Destinasi, Hospitalitas dan Perjalanan. Vol. 1 No. 1. 2017. 1-9.
Tanaya, D.R dan I. Rudianto. 2014. Potensi Pengembangan Ekowisata Berbasis Masyarakat di Kawasan Rawa Pening, Kabupaten Semarang. Jurnal Teknik PWK. Vol. 3. No. 1. 2014. 71-81.

Parroco, A.M., F. Vaccina, S. De Cantis, and M. Ferrante. 2012. Multi-destination Trips: A Survey on Incoming Tourism in Sicily, Discussion Paper. Economics, 2012-21, pp 19.

Ridlwan, M.A., S Muchsin dan Hayat. 2017. Model Pengembangan Ekowisata dalam Upaya Pemberdayaan Masyarakat Lokal.

Politik Indonesia: Indonesian Political Science Review. 2 (2). (2017). 141-158.

Wang, K., Zhang, C., Chen, H. et al. 2019. Karst Landscapes of China: Patterns, Ecosystem Processes and Services. Landscape Ecol 34, 2743-2763. 